\title{
Biochemical Investigations of Bowel Inflammation in Gastroschisis
}

\author{
JEAN GUIBOURDENCHE, DOMINIQUE BERREBI, EDITH VUILLARD, PASCAL DE LAGAUSIE, YVES AIGRAIN, \\ JEAN-FRANÇOIS OURY, AND DOMINIQUE LUTON
}

\author{
Department of Biology [J.G., D.B.], Department of Obstetrics [E.V., J.-F.O., D.L.], Department of Pediatric Surgery [P.L., Y.A.], \\ Hôpital Robert Debré APHP, 75235 Paris, France
}

\begin{abstract}
Neonates with gastroschisis have perivisceritis resulting from contact between the bowel and amniotic fluid. Here, we characterized the mediators involved in this inflammatory process in humans and ewes, to find a reliable marker of this process. We have diagnosed 41 cases of gastroschisis since 1995. Amniotic fluid sampled for karyotyping between 15 and 32 wk of gestation was also used to assay cytokines and inflammatory proteins. The findings were compared with those in 93 age-matched controls. Amniotic fluid cells were analyzed by means of cytology. Histologic examination of the bowel was performed when neonatal appendectomy was performed. The findings were compared with those obtained in a ewe model of gastroschisis. In gastroschisis, amniotic total protein, IL-6, IL-8, and ferritin levels were significantly higher than in controls. Gastroschisis was associated with significantly higher cell counts (mainly mononuclear cells) in amniotic fluid. At birth, macrophages were abundant in the fibrous peel covering the bowel. Similar results were obtained in the ewe model. Gastroschisis may be associated with a subchronic inflammatory process of variable intensity. This inflammation is restricted to the bowel wall and involves inflammatory cells such as macrophages, which may secrete ferritin, neopterin, and calprotectin. (Pediatr Res 60: 565-568, 2006)
\end{abstract}

$\mathrm{G}^{2}$ astroschisis is an abdominal wall defect in which various segments of the bowel extrude through a small paraumbilical defect, usually situated on the right side. Prenatal diagnosis is usually made in the second trimester, when sonography shows bowel loops floating freely in amniotic fluid (1). Gastroschisis is rare (1/6000 to $1 / 10,000$ pregnancies) and generally isolated. Its cause is unknown, but probably involves premature regression of the omphalomesenteric artery, leading to failure of the mesodermal components of the abdominal wall (2). The survival rate exceeds $90 \%$. Factors of poor prognosis include intrauterine growth retardation, oligohydramnios, and the degree of perivisceritis at birth (3).

Perivisceritis in this setting is due to aseptic peritonitis, probably secondary to prolonged exposure of the bowel to amniotic fluid (4). The components of amniotic fluid involved in this reaction are controversial, but we have previously obtained evidence incriminating high levels of digestive enzymes, which may aggress the gut; this is also supported by experimental findings $(5,6)$. The inflammatory process includes edema, fibrin deposi-

Received January 11, 2006; accepted June 24, 2006.

Correspondence: Dominique Luton, M.D., Ph.D., Service de Gynécologie-obstétrique, Hôpital Robert Debré, 48 boulevard Sérurier, 75235 Paris XIX, France; e-mail: dominique.luton@rdb.aphp.fr

DOI: 10.1203/01.pdr.0000242344.22638.94 tion, and cell infiltration of the bowel wall $(7,8)$. We and Morrison et al. $(9,10)$ have shown on restricted studies that the degree of inflammation should be used to evaluate gut damage. Here we studied a series of human cases of gastroschisis and used a ewe experimental model to examine the involvement of inflammatory cells and soluble mediators.

\section{MATERIALS AND METHODS}

Patients and samples. Forty-one human pregnancies complicated by fetal gastroschisis have been managed at Robert Debré Hospital since 1995. Gastroschisis was diagnosed between 15 and 32 wk of pregnancy by a single reference sonographer (E.V.) after visualization of free loops of bowel moving in the amniotic cavity, as shown by a Hitachi Katana device with a 3.5-MHz sector transducer. With approval from Robert Debré Hospital ethics committee and maternal consent, amniotic fluid sampling was performed within 3 wk after diagnosis, to rule out karyotype abnormalities. None of the cases analyzed here was associated with multiple malformations or chromosome abnormalities. At birth, the neonates were admitted to the neonatal intensive care unit. They were treated surgically, including appendectomy when judged appropriate by the surgical team.

Ninety-three amniotic fluid samples from age-matched pregnancies were used as controls. They were obtained for karyotyping, for reasons of maternal age (>38 y), positive maternal Down's syndrome screening test, short femur, or major cardiac disorders. All the control fetuses were free of gastrointestinal abnormalities and polymalformations on sonography, and all had a normal karyotype.

Ewe experimental model. The experimental protocol was approved by the local ethics committee and by the School of Surgery. We used southern prealpine ewes. Pregnancy was diagnosed by early repeated ultrasound scanning. Gastroschisis $(n=16)$ was created in midpregnancy $(\mathrm{d} 70-80)$ by means of an endoscopic intrauterine technique, as previously described $(11,12)$. Amniotic fluid was sampled $10 \mathrm{~d}$ after surgery in the gastroschisis group, and also in age-matched control ewes $(n=9)$. The fetuses were killed at the end of pregnancy (d 140) during cesarean section, before the onset of labor, and the fetal bowel was surgically removed for analysis.

Cellular analysis of amniotic fluid. In the hour following sampling, in humans and ewes, $200 \mu \mathrm{L}$ of homogenized amniotic fluid was placed on a slide (Cytofunnel, Thermo Electron, Waltham, MA) and centrifuged (300 g, $5 \mathrm{~min}$ ). The slide was then stained with May-Grünwald-Giemsa for microscopic analysis.

Biochemical analysis of amniotic fluid. Two milliliters of amniotic fluid was centrifuged $\left(4^{\circ} \mathrm{C}, 10 \mathrm{~min}, 2000 \mathrm{~g}\right)$ and immediately stored at $-80^{\circ} \mathrm{C}$ for no more than 1 month until use. Cytokines [IL-6, IL-8, tumor necrosis factor- $\alpha$ (TNF- $\alpha$ ), IL-1 $\beta$, neopterin, and calprotectin [Calprest $(B])$ were measured with EIA kits (Beckman Coulter-Immunotech, Paris, France, and Eurospital, Trieste, Italy, respectively). Samples were diluted $1 / 10$ and 1/500, respectively, before IL- 6 and calprotectin assay. Intra- and interassay variability were below $8 \%$ and $15 \%$, respectively. Detection limits were $3 \mathrm{ng} / \mathrm{L}$ IL-6, $5 \mathrm{ng} / \mathrm{L}$ TNF- $\alpha, 1.5 \mathrm{ng} / \mathrm{L}$ IL-1 $\beta$, $8 \mathrm{ng} / \mathrm{L} \mathrm{IL}-8,0.2 \mu \mathrm{g} / \mathrm{L}$ neopterin, and $5 \mu \mathrm{g} / \mathrm{L}$ calprotectin.

Total protein, albumin, ferritin, C-reactive protein (CRP), and $\alpha 1$-acid glycoprotein were assayed on Hitachi 911 and Advia 1650 automates (Roche Diagnostics, Basel, Switzerland), using a spectrophotometric method for total protein (Proteines Urinaires, Bio Mérieux, Marcy l'Etoile, France) and immunoturbidimetric methods for the other proteins (Tina-quant albumin, Tinaquant ferritin, Roche Diagnostic; CRP and $\alpha 1$-acid glycoprotein, Randox, Oceanside, CA). Intra- and interassay variability were below 5\% and 9\%, respectively. Detection limits were $0.05 \mathrm{~g} / \mathrm{L}$ total protein, $6 \mathrm{mg} / \mathrm{L}$ albumin, $5 \mu \mathrm{g} / \mathrm{L}$ ferritin, $5 \mathrm{mg} / \mathrm{L} \mathrm{CRP}$, and $0.2 \mathrm{~g} / \mathrm{L} \alpha 1$-acid glycoprotein. Procalcitonin 
was assayed on a Kryptor automate (Brahms Diagnostica, Berlin, Germany); intra- and interassay variability were below $6.8 \%$ and $9.2 \%$, respectively; the detection limit was $0.06 \mu \mathrm{g} / \mathrm{L}$.

Electrophoresis was performed with the Hydrasys system (Sebia, Inc., Norcross, GA). Concentrated amniotic fluid samples were applied to agarose gel (Hydragel Protein 15/30, Sebia, Inc.). The different protein fractions were then stained with amino black and quantified by densitometry $(570 \mathrm{~nm})$. Only total protein and ferritin assay and protein electrophoresis were done in ewes.

Bowel histology. Immediately after appendectomy (humans) or after sacrifice (ewes), the surgical gut specimens were sampled, fixed in formalin (3.7\%, pH 4), and macroscopically examined. Specimens were embedded in paraffin and 5- $\mu \mathrm{m}$ medio-sagittal sections were stained with hematoxylineosin-safran for microscopic examination.

Statistical analysis. All data were analyzed with StatView 4R software for Macintosh (SAS Institute, Cary, NC). Concentrations are expressed as median and range in each group (control and gastroschisis). Simple regression analysis was implemented with the least-squares method and Spearman's rank correlation coefficient test was used to establish associations among the biochemical markers. For each marker, the control group and the gastroschisis group were compared by using the Mann-Whitney $U$ test. $p$ Values below 0.05 were considered significant.

\section{RESULTS}

Amniotic fluid cytochemistry. In both human and ewe controls, amniotic fluid contained only a few epithelial cells (Fig. 1, $A$ and $B$ ). Gastroschisis was associated with significantly higher cell counts $\left(80 \pm 50\right.$ versus $20 \pm 17$ cells $\left./ \mathrm{mm}^{3}\right)$. The cells consisted mainly of mononuclear cells and a few polymorphonuclear leukocytes in both humans and ewes (Fig. 1, $C$ and $D$ ).

Amniotic fluid biochemistry. In controls, levels of IL-1 $\beta$, TNF- $\alpha$, CRP, $\alpha 1$-acid glycoprotein, and procalcitonin were low or undetectable, whereas albumin, IL-6, IL-8, ferritin, neopterin, and calprotectin were always detectable (Table 1).

In human gastroschisis, IL-6 and IL-8 levels were significantly increased $(p<0.001)$, by factors of 13 and 4 , respectively, compared with matched controls. IL- $1 \beta$ and TNF- $\alpha$ levels were low or undetectable in human subjects. Total protein $(p=0.006)$ and albumin $(p=0.001)$ levels were increased, respectively, by 1.5 - and 1.7 -fold, whereas CRP, $\alpha 1$-acid glycoprotein, and procalcitonin levels were normal. The amniotic fluid protein electrophoresis patterns were identical in gastroschisis

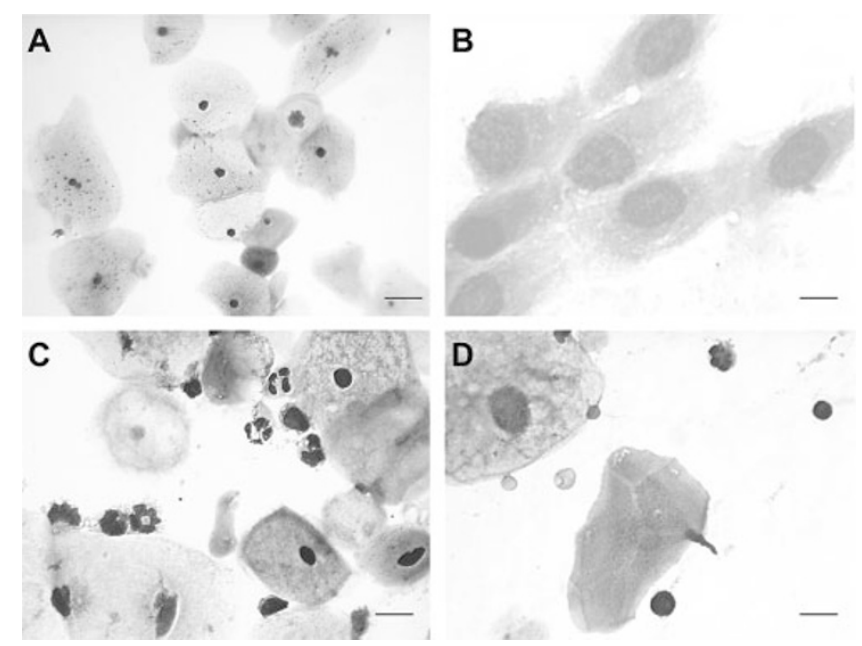

Figure 1. Amniotic fluid cytology. Amniotic fluid was homogenized, dropped on a slide, centrifuged, and stained with May-Grünwald-Giemsa. In both human $(A)$ and ewe controls $(B)$, amniotic fluid contained only a few epithelial cells, whereas mononuclear cells and a few polymorphonuclear leukocytes were present in gastroschisis $(C, D)$. Scale bar, $20 \mu \mathrm{m}$. cases and controls with no decrease in albumin, the major protein fraction (data not shown). Amniotic fluid ferritin levels were 3 -fold higher $(p=0.001)$ in gastroschisis cases than in controls. Neopterin levels and calprotectin levels were not significantly increased in gastroschisis but showed wide interindividual differences. The only inter-correlation among these markers was between albumin and total protein.

In the ewe model, total protein and ferritin concentrations were, respectively, 3 -fold and 1.9-fold higher than in control ewes, whereas the electrophoretic patterns were similar (data not shown).

Bowel histology. At birth, the bowel of both humans ( $n=$ $13)$ and ewes $(n=9)$ with gastroschisis was covered by a fibrous peel. The thickness of the muscularis intestinalis and the serous layer was increased 2-fold and 6-fold, respectively (Fig. 2). Within and below the serous layer, fibrosis was associated with mild infiltration by polymorphonuclear leukocytes and mononuclear cells (i.e. macrophages in humans, and lymphocytes in ewes).

\section{DISCUSSION}

At least $25 \%$ of neonates with gastroschisis exhibit severe perivisceritis, which appears to result from prolonged contact between the bowel and amniotic fluid (4-6). We and others have conducted preliminary studies of this inflammatory process $(9,10,13)$. We have also developed an experimental ewe model of gastroschisis to study the involvement of amniotic digestive enzymes and the potential benefit of amnioinfusion or amnioexchange $(11,12)$. Here, we conducted an exhaustive biochemical investigation of the inflammatory process with the overriding aim of identifying an amniotic fluid component reflecting the degree of gut damage. We concomitantly developed a sheep model to be able to examine the perivisceritis both macroscopically and histologically, by comparison to amniotic fluid biochemistry, at precisely the same time after the insult.

We confirm the presence of perivisceritis at birth, in both humans and model ewes, characterized by an inflammatory "peel" $(7,8,11)$. Inflammation appeared to be restricted to the gut because the placentas were otherwise normal when examined (not shown). At present, there is no reliable way of predicting before birth the degree of perivisceritis and postnatal digestive function. The peel is often present at birth, but its thickness is highly variable, mainly because of differences in the duration of contact between the bowel wall and amniotic fluid, and possibly the quantitative composition of the latter, and the amnioinfusion or amnioexchange performed.

The increased thickness of the muscularis intestinalis and the serous layer results from fibrosis and cellular infiltration. We noted certain differences in this bowel infiltration between humans and ewes. It was composed mainly of mononuclear cells involving macrophages in both species, but with polymorphonuclear leukocytes in humans and lymphocytes in the ewe model. This may reflect differences in the immune response among species $(14,15)$. The degree of infiltration was also variable among human individuals, possibly owing to differences in the sampling time relative to the date of onset, the composition of the amniotic fluid and the amnioexchanges 
Table 1. Amniotic fluid biochemistry

\begin{tabular}{|c|c|c|c|c|}
\hline & \multicolumn{2}{|c|}{ Human } & \multicolumn{2}{|c|}{ Ewe } \\
\hline & Controls & Gastroschisis & Controls & Gastroschisis \\
\hline IL-6 (ng/L) & $329(60-2434)$ & $4524 *(219-12,973)$ & - & - \\
\hline IL-8 (ng/L) & $421(31-900)$ & $1817 *(748-2000)$ & - & - \\
\hline $\mathrm{IL}-1 \beta(\mathrm{ng} / \mathrm{L})$ & $3.9(1.5-22)$ & $4.4(1.5-42.3)$ & - & - \\
\hline $\mathrm{TNF}-\alpha(\mathrm{ng} / \mathrm{L})$ & $11.5(5-82)$ & $7(5-46)$ & - & - \\
\hline Ferritin $(\mu \mathrm{g} / \mathrm{L})$ & $85.5(17-130)$ & $269 *(25-653)$ & $5(5.0-6.3)$ & $9.3 *(5.3-11.4)$ \\
\hline Neopterin $(\mu \mathrm{g} / \mathrm{L})$ & $2.6(1.2-8.2)$ & $3.4(1.8-11.2)$ & - & - \\
\hline Calprotectin $(\mu \mathrm{g} / \mathrm{L})$ & $3425(225-13,900)$ & $3975(950-15,700)$ & - & - \\
\hline Total protein $(\mathrm{g} / \mathrm{L})$ & $2.7(1.6-3.7)$ & $4.1 *(2.6-10.2)$ & $2.5(1.1-3.9)$ & $8.1 *(3.6-12.0)$ \\
\hline Albumin $(\mathrm{g} / \mathrm{L})$ & $2.2(1.1-2.8)$ & $3.8 *(2.1-9.0)$ & - & - \\
\hline$\alpha 1$-Acid glycoprotein $(\mathrm{g} / \mathrm{L})$ & $0.2(0.2-0.4)$ & $0.3(0.2-0.7)$ & - & - \\
\hline $\mathrm{CRP}(\mathrm{mg} / \mathrm{L})$ & $5.4(5-8)$ & $5.3(5-9)$ & - & - \\
\hline Procalcitonin $(\mu \mathrm{g} / \mathrm{L})$ & $1.8(0.06-2.9)$ & $2.2(0.06-3.2)$ & - & - \\
\hline
\end{tabular}

Amniotic fluid was assayed for cytokines (IL-6, IL-8, TNF- $\alpha$, IL-1 $\beta$, ferritin, neopterin total protein, albumin, C reactive protein (CRP), and calprotectin. Concentrations are expressed as median and range. Detection limits were assigned to undetectable levels. $p$ Values $<0.05$ were considered significant $(*)$.
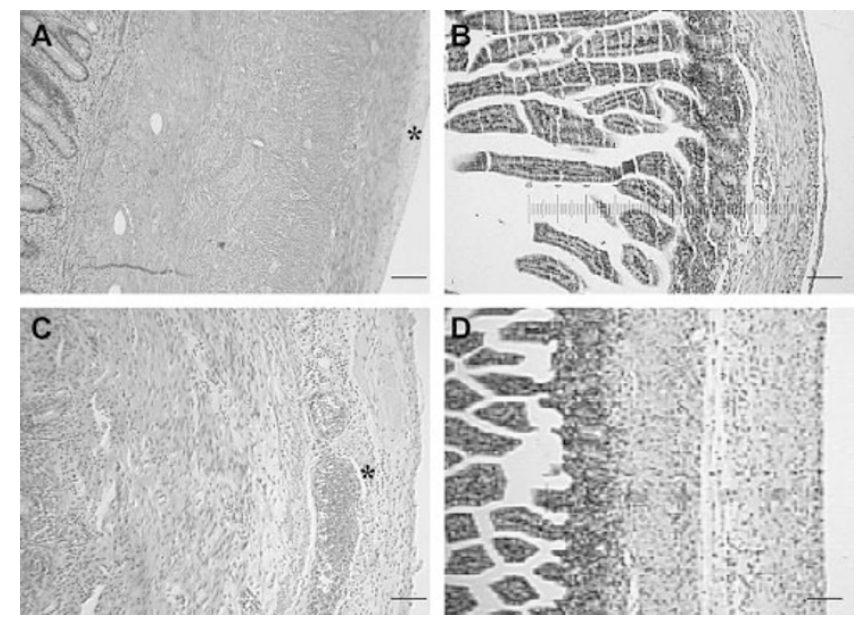

Figure 2. Bowel histology. When neonatal appendectomy was necessary, bowel specimens were fixed in formalin and stained with hematoxylin-eosinsafran. In both human and ewe gastroschisis, the bowels were covered by a fibrous peel, with a significant increase in the thickness of both the muscularis intestinalis and the serous layer. (A) Human controls, $(B)$ ewe controls, $(C)$ human gastroschisis, $(D)$ ewe gastroschisis. Scale bar, $50 \mu \mathrm{m}$.

or the amnioinfusions performed. Polymorphonuclear leukocytes are indeed associated with an acute-phase response, whereas macrophages are observed in chronic or subchronic inflammation which results from tissue destruction and inflammatory cell recurrent recruitment. Thus, gut perivisceritis at birth reflects the final step of this process, resulting mainly from the duration of the injury.

As fetal gut biopsy was not ethically feasible, we examined the cells and soluble mediators present in amniotic fluid sampled for karyotyping. The cellularity of amniotic fluid was increased in gastroschisis, in keeping with the results of a previous study (9). These cells, i.e. mononuclear cells and polymorphonuclear leukocytes, are likely to be released from the inflamed gut into amniotic fluid, as the placenta and fetal membranes were not inflamed.

We then investigated the biochemical mediators these cells might secrete. In human gastroschisis, IL-6 and IL-8 levels were increased, whereas TNF- $\alpha$ and IL- $1 \beta$ levels were normal, pointing to a subchronic inflammatory process. During the acute phase, leukocytes secrete the alarm cytokines TNF- $\alpha$ and IL-1 $\beta$ at the inflammatory focus (16). These two cytokines have pleiotropic effects on stromal and endothelial cells and inflammatory cells, inducing the production of IL-6, which in turn down-regulates TNF- $\alpha$ and IL- $1 \beta$ production. In addition, macrophages present in the gut wall are able to produce large amounts of IL-6 (17).

Cytokine stability in amniotic fluid is controversial, and cytokine measurement is not always easy to perform in this medium (18). As IL-6 induces systemic production of many inflammatory proteins, we investigated classical markers of inflammation (protein electrophoresis, CRP, and $\alpha 1$-acid glycoprotein), which may either transudate from the bowel wall into amniotic fluid or be locally produced (19). Active inflammatory gut diseases such as Crohn's disease are accompanied by elevated CRP levels in neonates, contrary to ulcerative colitis and irritable bowel syndrome (20). We observed no difference between gastroschisis cases and controls, suggesting either the absence of systemic inflammation or immature fetal hepatic protein synthesis (21). The increase in total protein observed here may result from transudation from the gut wall, as reflected by the concomitant increase in albumin levels. Digestive enzymes, levels of which are known to be increased in gastroschisis, may also contribute to the increase in total protein (10). When studying specific and stable biochemical markers of inflammatory cells, we observed a significant increase in ferritin levels both in ewes and in human gastroschisis, whereas the increase in neopterin and calprotectin concentration in the amniotic fluid was not significant. Ferritin is a ubiquitous glycoprotein involved in the uptake, storage, and release of iron $(22,23)$. It originates from several tissues, including the gut, and various cell types, including macrophages $(24,25)$. Its serum levels are increased in chronic inflammation. The observed increase in the amniotic fluid ferritin concentration may reflect the increase numbers of macrophages present in the gut during gastroschisis. However, neopterin and calprotectin levels were not significantly increased. Neopterin is a pteridine derivative mainly secreted by macrophages and monocytes after stimulation by interferon gamma, which itself is secreted by activated lymphocytes (26-28). Calprotectin is a calcium-binding protein abundant in neutrophils, monocytes, macrophages and squamous epithelial cells $(29,30)$. Fecal calprotectin is a reliable marker of 
intestinal inflammation. Increased calprotectin levels have been detected in intestinal diseases associated with inflammation such as necrotizing enterocolitis, and its quantitation provides a measure of the degree of tissue inflammation in adults with irritable bowel disease $(31,32)$. Neopterin and calprotectin appears to play a regulatory role in the inflammatory process as well as calprotectin $(33,34)$. Calprotectin and neopterin expression by macrophages and monocytes depends on their differentiation status $(28,29)$. In children, calprotectin-secreting macrophages in inflamed mucosa might be newly recruited. The absence of any significant increase in amniotic neopterin and calprotectin may reflect gut inflammatory cells heterogeneity (35). Further investigations in vivo and in vitro should be made to characterize those cells focusing on their differentiation status.

We found that gastroschisis was often associated with bowel inflammation, which led to a perivisceritis at birth in both humans and ewes. At the time of karyotyping, the inflammatory process had already spread, but to various extents among patients. This variability is likely to be due to the fact that, gut inflammation is a dynamic process that involves different cell types at different stages of activation, influenced by the duration of bowel exposure to amniotic fluid, and by the precise composition of amniotic fluid. This composition is likely fluctuate with bile vomiting or fecal losses associated with gastroschisis, and participates in the development of peritonitis and perivisceritis. This process involves inflammatory cells which are likely to be released from the gut wall into amniotic fluid, as shown by our cytological findings. We were able to measure the mediators secreted into amniotic fluid but, unfortunately, we failed to identify a biochemical index of bowel injury, owing to marked interindividual variability. Thus, individual follow-up of ferritin, neopterin, and calprotectin levels would probably be more informative, providing that the initial sample is obtained as early as possible in the inflammatory process. Inflammatory mediators are known to up-regulate enzymes involved in extracellular matrix degradation (36). They synthesize and release matrix metalloproteases (MMP), which degrade collagen in the fibrous cap. They may directly contribute to the alteration of the gut wall (37). The value of measuring this inflammatory process to predict gut function, and its relationship with postnatal and postoperative return of bowel function is under investigation.

Acknowledgments. The authors thank Professor Ghislaine Sterkers for her critical advice. We also thank Mireille Nicolas for her technical assistance.

\section{REFERENCES}

1. Gabrielli S, Reece EA 1992 Gastrointestinal and genitourinary anomalies. In: Reece EA, Hobbins JC, Mahomey MJ, Petrie RH (eds) Medicine of the Fetus and the Mother. JB Lippincott Company, Philadelphia, pp 551-577

2. Larsen WJ 1993 Development of the gastrointestinal tract. In: Larsen WJ (eds) Human Embryology. Churchill-Livingstone, New York, pp 224-234

3. Eurenius K, Axelsson O 1994 Outcome for fetuses with abdominal wall defects detected by routine second trimester ultrasound. Acta Obstet Gynecol Scand 73:25-29

4. Langer JC, Longaker MT, Crombleholme TM, Bond SJ, Finkbeiner WE, Rudolph CA, Verrier ED, Harrison MR 1989 Etiology of intestinal damage in gastroschisis. Effect of amniotic fluid exposure and bowel constriction in afetal lamb model. J Pediatr Surg 24:992-997

5. Akgur FM, Ozdemir T, Olguner M, Aktug T, Ozer E 1998 An experimental study investigating the effects of intraperitoneal human neonatal urine and meconium on rat intestines. Res Exp Med (Berl) 198:207-213
6. Api A, Olguner M, Hakguder G, Ates O, Ozer E, Akgur FM 2001 Intestinal damage in gastroschisis correlates with the concentration of intraamniotic meconium. $\mathrm{J} \mathrm{Pe}$ diatr Surg 36:1811-1815

7. Tibboel D, Raine P, McNee M, Azmy A, Kluck P, Young D, Molenaar JC 1986 Developmental aspects of gastroschisis. J Pediatr Surg 21:865-869

8. Amoury RA, Beatty EC, Wood WG, Holder TM, Ashcraft KW, Sharp RJ, Murphy JP 1988 Histology of the intestine in human gastroschisis-relationship to intestinal malfunction: dissolution of the "peel" an its structural characteristics. J Pediatr Surg 23:950-956

9. Morrison JJ, Klein N, Chitty LS, Kocjan G, Walshe D, Goulding M, Geary MP, Pierro A, Rodeck CH 1998 Intra-amniotic inflammation in human gastroschisis: possible aetiology of postnatal bowel dysfunction. Br J Obstet Gynaecol 105:1200-1204

10. Burc L, Voluménie JL, De Lagausie P, Guibourdenche J, Oury JF, Vuillard E, Sibony O, Blot P, Saizou C, Luton D 2004 Amniotic fluid inflammatory proteins and digestive compounds profile in fetuses with gastroschisis undergoing amnioexchange. BJOG 111:292-297

11. Luton D, De Lagausie P, Guibourdenche J, Peuchmaur M, Sibony O, Aigrain Y, Oury JF, Blot P 2000 Influence of amnioinfusion in a model of in utero created gastroschisis in the pregnant ewe. Fetal Diagn Ther 15:224-228

12. De Lagausie P, Guibourdenche J, De Buis A, Peuchmaur M, Oury JF, Aigrain Y, Sibony O, Luton D 2002 Esophageal ligature in gastroschisis. J Pediatr Surg 37:1160-1104

13. Luton D, De Lagausie P, Guibourdenche J, Oury JF, Vuillard E, Sibony O, Farnoux C, Aigrain Y, Blot P 1997 Prognostic factors of prenatally diagnosed gastroschisis. Fetal Diagn Ther 12:7-14

14. Gravett MG, Witkin SS, Novy MJ 1994 A non human primate model for chorioamnionitis and preterm labor. Semin Reprod Endocrinol 12:246-262

15. Berry SM, Romero R, Gomez R, Puder KS, Ghezzi F, Cotton DB, Bianchi DW 1995 Premature parturition is characterized by in utero activation of the fetal immune system. Am J Obstet Gynecol 173:1315-1320

16. Luster AD 1998 Chemokines-chemotactic cytokines that mediate inflammation. N Engl J Med 338:436-445

17. Baumann H, Gauldie J 1994 The acute phase response. Immunol Today 15:74-80

18. Heney D, Whicher JT 1995 Factors affecting the measurement of cytokines in biological fluids: implications for their clinical measurement. Ann Clin Biochem 32:358-368

19. Fey GH, Hocke GM, Wilson DR, Ripperger JA, Juan TS, Cui MZ, Darlington GJ 1994 Cytokines and the acute phase response of the liver. In: Arias IM, Boyer JL, Fausto N, Jakoby WB, Schachter DA, Shafritz DA (eds) The Liver: Biology and Pathobiology, 3rd Ed, Raven Press, New York, pp 113-143

20. Vermeire S, Van Assche GV, Rutgeerts P 2004 C-reactive protein as a marker for inflammatory bowel disease. Inflamm Bowel Dis 10:661-665

21. Bienvenu J, Sann L, Bienvenu F, Lahet C, Divry P, Cotte J, Bethenod M 1981 Laser nephelometry of orosomucoid in serum of newborns. Reference intervals and relation to bacterial infections. Clin Chem 27:721-726

22. Lash A, Saleem A 1995 Iron metabolism and its regulation. A review. Ann Clin Lab Sci 25:20-30

23. Harrison PM, Arosio P 1996 The ferritins: molecular properties, iron storage function and cellular regulation. Biochim Biophys Acta 1275:161-203

24. Theurl I, Ludwiczek S, Eller P, Seifert M, Artner E, Brunner P, Weiss G 2005 Pathways for the regulation of body iron homeostasis in response to experimental iron overload. J Hepatol 43:711-719

25. Recalcati S, Taramelli D, Conte D, Cairo G 1998 Nitric oxide-mediated induction of ferritin synthesis in J774 macrophages by inflammatory cytokines: role of selective iron regulatory protein-2 down regulation. Blood 91:1059-1066

26. Wachter H, Fuchs D, Hausen A, Reibnegger G, Werner ER 1989 Neopterin as marker for activation of cellular immunity: immunologic basis and clinical application. Adv Clin Chem 27:81-141

27. Radunovic N, Kuczynski E, Rebarber A, Nastic D, Lockwood CJ 1999 Neopterin concentrations in fetal and maternal blood: a marker of cell-mediated immune activation. Am J Obstet Gynecol 181:170-173

28. Huber C, Batchelor JR, Fuchs D, Hausen A, Lang A, Niederwieser D, Reibnegger G, Swetly P, Troppmair J, Wachter H 1984 Immune response-associated production of neopterin: release from macrophages preliminary under control of interferongamma. J Exp Med 160:310-316

29. Striz I Trebichavsky 2004 Calprotectin - a pleiotropic molecule in acute and chronic inflammation. Physiol Res 53:245-253

30. Johne B, Fagerhol MK, Lyberg T, Prydz H, Brandtzaeg P, Naess-Andresen CF, Dale I 1997 Functional and clinical aspects of the myelomonocyte protein calprotectin. Mol Pathol 50:113-123

31. Carroll D, Corfield A, Spicer R, Cairns P 2003 Faecal calprotectin concentrations and diagnosis of necrotising enterocolitis. Lancet 361:310-311

32. Tibble JA, Bjarnason I 2001 Non invasive investigation of inflammatory bowel disease. World J Gastroenterol 7:460-465

33. Hoffmann G, Schobersberger W, Frede S, Pelzer L, Fandrey J, Watcher H, Fuchs D, Grote J 1996 Neopterin activates transcription factor nuclear factor-kappa B in vascular smooth muscle cells. FEBS Lett 391:181-184

34. Roth J, Vogl T, Sorg C, Sunderkotter C 2003 Phagocyte-specific S100 proteins: a novel group of proinflammatory molecules. Trends Immunol 24:155-158

35. Allison MC, Cornwall S, Poulter LW, Dhillon AP, Pounder RE 1988 Macrophage heterogeneity in normal colonic mucosa and inflammatory bowel disease. Gut 29:1531-1538

36. Zouridakis E, Avanzas P, Arroyo-Espliguero R, Fredericks S, Kaski JC 2004 Markers of inflammation and rapid coronary artery disease progression in patients with stable angina pectoris. Circulation 110:1747-1753

37. Naito Y, Yoshikawa T 2005 Role of matrix metalloproteinases in inflammatory bowel disease. Mol Aspects Med 26:379-390 